\title{
REVIEWS
}

\section{Showing Our Colours: Afro-German Women Speak Out}

Edited by May Opitz, Katharina Oguntoye and Dagmar Schultz

Open Letters: London 1992, ISBN $1857890256, £ 10.99,239 p p$

Showing Our Colours is a welcome publication which, in keeping with the Open Letters philosophy, combines the warmth and intimacy of exchanges between friends with the vigour of issues publicly addressed. Lest the English readership jump to the conclusion that minority women in Germany are only just discovering themselves, it is as well to bear in mind that the German original, Farbe Bekennen, came out in 1984. This places it a year in advance of The Heart of the Race, the first nonfiction book to address the experience of black women in Britain (Bryan,' Dadzie and Scafe, 1985). Nineteen eighty-four was also the year in which the debate on racism within feminism led Feminist Review, at that time still an all-white collective, to hand its editorial authority over to an ad hoc group of black women (which included myself), invited to guest edit Many Voices, One Chant: Black Feminist Perspectives. Showing Our Colours differs from these early British publications in several important ways.
The Heart of the Race gestated in the belly of a self-defining, autonomous movement for many years, before finally coming out after a decade of black women's organization and activism, which had given its authors a sense of politics, and of the need for presenting a collective analysis rather than merely revealing the scarified underbelly of black womanhood. Their insistent use of 'we' was a political decision, reflecting the authors determination to assert the unification of black women, and to celebrate the shared leap in awareness that black feminism signified. ${ }^{1}$ It paved the way for subsequent exploration of all the diversities that had been grouped some less comfortably than others within the term 'black'. Farbe Bekennen does not have this strident assertiveness, presumably because it preceded collective action. In one of the introductions, Gail Lewis informs us that, just as its editors had hoped, publication led to the first national organization of black Germans, Initiative Schwarze Deutsche. It is a more exploratory book, and although there is an historical chapter, drawn from May Opitz's Masters dissertation, the bulk of the book presents the stories of isolated individuals with an intimacy that is at once raw and engaging. It does seem as if the two supportively written introductions by veterans of the 
British (Gail Lewis) and American (Audre Lorde) black women's movements, try to locate these very separate testimonies in an existing framework, an intention that is more worthy than necessary. They do not succeed in altering the fact that the strongest declaration of collectivity lies in the title; a title that signifies the birth of a new group identity, to be built out of the need to grow beyond the painful experience of German racism.

The chosen term of identification - 'Afro-German' - differs too: black women in Britain tend to name themselves in ways which stress the non-British aspect of their authors: we have 'Black feminists' 'Black women' 'Afro-Caribbean women' 'Asian women' 'African women'. Britishness appears to be regarded with some distaste, or at least with disinterest, even by those who really have no other place to go. Black women in Germany are not evading their Germanness in their selfappellation, despite the fact that at least as far as these accounts go, it is certainly no easier to be German and black than it is to be British and black. Perhaps it is due to the fact that the contributors have all been born and raised in Germany, most of them by white German mothers. Their experiences do not include any memory of migrating from a childhood location in the Caribbean, Asia or Africa, and few seem to harbour dreams of 'returning' to that source. These Afro-Germans are more locked in to Germany, and show little real identification with the places that their fathers came from; whether they were American soldiers or Africans. The one who did visit 'home' with her father gives an honest account of how unbearable she found it, distanced as she was by the language and culture of Ethiopia, doubly so because she was supposed to be one of them, but was not.

Germany is not a place harbouring many notions of pluralism.
National identity is racial identity Aryanness, biology. It would seem that 'non-Aryans' are as much nonpersons today as they were during the Nazi regime. Perhaps the hybrid nature of most of the contributors explains the depth of the feeling of rejection in these voices. Perhaps 'impure' Germans are abhorred in special ways, because they incarnate the fear of contamination, so central to the Aryan creed.

Like many of the women's publications in the 'speak out' genre, it is a cathartic speaking bitterness which makes rather bleak reading. Black women growing up in Germany have had a miserable time of it, if this book is representative of that whole experience. Or can we attribute the wholly negative impression that is conveyed to the birth pains of beginning to articulate, the necessary airing of pent-up unhappiness, that may one day clear the way, freeing hearts and minds for fuller reflection? The enormous courage and forbearance that black women must have to survive at all does not change the fact that Showing Our Colours is a joyless set of testimonies. Reading it means opening up the buried hurts of childhoods spent in whitedominated countries, rupturing whatever scar tissue has held down the discomforts endured, and for those who have visited this space before, empathizing with a great deal of what is said by these women. Many black women raised in Britain will recognize what it means to live blighted with eczema and asthma, subjected to constant ridicule in the playgrounds. A great many here too have grown up in the children's homes of a land that had no place for 'half-caste' children, and where their white mothers could not bear to pay the price of raising a brown child. Many will remember grannies who loved them, but were perpetually afraid of being embarrassed, who scraped back their hair and made sure they never wore colours that were too bright. 
However, not even the older black Britons will have survived the Nazi concentration camps, escaped from sterilization clinics, and, more remarkably still lived on in Danzig or Berlin. Black women in Germany were hunted down by 'the watchdogs' who were their neighbours, and spent their childhoods being hounded out of bible circles, gymnasiums, school outings, stigmatized as nonAryans in a state where this was official policy, where white supremacy was so total that the nightmares persisted well after the Nazi defeat, into adulthood.

For the post-war generation, there was the new and additional hatred of being identified with the occupying American troops, some of whom were black, and who left tens of thousands of little 'mulatto problems' behind them, to grow up to the racist taunts of a defeated nation.

These 'Afro-German' women do not mention anything positive that they may have derived from Germany or Germans, or any connexions with an aspect of German society that has rejected the fascist past, which challenges the rising tide of racism in the present. Isolated from one another, and despised by whites, they express the hope that the publication of their testimonies will bring them together. Then they may be able to begin to interrogate the society that has shaped them, and for which there are no expressions of affection. At best there is a resigned acknowledgement that it is what I know, where I was brought up', and this cannot be enough.

I found myself wondering if all newly invented identities must either be forced out painfully, harking back to a history of suffering, or be so celebratory that they rely on glorification of a mythical, unified past? Perhaps it is only later, after the bitterness has been spoken and shared, that Afro-German women will be able to celebrate their identity, and then to recover, to speak of the things that have made/enabled them to stay/survive, to take hold of their future, and instead of being passive products of history and racism, to realize the dynamic growth that is born in those who have fought many battles, and lived on.

But what can begin to grow in today's Germany? Two thousand race attacks in the last year, a resurgence of open support for Nazism, calls for concentration camps to be reopened and non-Aryans deported en masse. What will Initiative Schwarze Deutsche be able to do for black people in such a place? Who will be its allies?

British black feminists have tended to have their eyes on the other side of the Atlantic, on the impressive outpourings of American sisters, rather than on forging links with other black Europeans. '1992' has been and gone, and Europe continues to close in on itself, locking Europe's minorities in together, for better or for worse. Germany, and France, Switzerland, Italy and the others are all suddenly much closer, so perhaps it is time to turn the black feminist gaze closer to home.

The availability of Showing Our Colours in English is a small but significant step towards opening up communications among black women in Europe. It has come at a time when national-level organizations of black women in Britain no longer exist. Perhaps the publishers harboured dreams of a renewed women's internationalism, of new pan-European alliances and exchanges. International black women's festivals in Munich, Dresden, Berlin - Amsterdam, Paris, London, Oslo and Stockholm? Exchanges between community groups, theatre groups, film collectives, scholars and activists - is there any shortage of possibilities, once the channels are opened?

\section{Amina Mama}




\section{Notes}

The editorial group are sorry to learn that Open Letters has already ceased publication.

1 It provoked negative reactions amongst some (white) reviewers who felt alienated by this new, black, use of 'we', while others went so far as to argue that black feminism as a whole must be divisive because it made them feel left out.

\section{References}

BRYAN, B., DADZIE, S. and SCAFE, S. (1985)

The Heart of the Race London: Virago. FEMINIST REVIEW (1984) No. 17 Many Voices, One Chant: Black Feminist Perspectives.
Women's Orients: English Women and the Middle East, 1718-1918

Billie Melman

Macmillan: Basingstoke 1992,

ISBN 033346300 5, £45.00 Hbk

\section{Discourses of Difference: An Analysis of Women's Travel Writing and Colonialism}

Sara Mills

Routledge: London and New York 1991, ISBN 041504629 7, £30.00 Hbk

\section{Imperial Eyes: Travel Writing and \\ Transculturation}

\section{Mary Louise Pratt}

Routledge: London and New York 1992, ISBN 041506095 8, £11.95 Pbk ISBN $041502675 \mathrm{X}$, £35.00 Hbk

These three books all represent efforts to take on and develop Edward Said's argument as to the discourse of 'Orientalism'. Said argued in his seminal work, Orientalism (1985), that the Orient was almost a European invention and that Orientalism, a way of thinking about the Orient, provided ways in which the West was able to dominate, restructure and have authority over the Orient. As many feminists have pointed out in the last fifteen years, Said did not see gender as relevant to his analysis. The flowering of work inspired and stimulated by his rethinking of the relation between the West and the Orient, however, has included a certain amount of new scholarship from feminists. Oddly,
Mary Louise Pratt never cites Said but it is hard to imagine that her analysis of travel writing could have existed without him. Sara Mills and Billie Melman are both quite clear about their debt to Said, and their challenge to his gender-neutral analysis. The three books share an interest in travel writing and the ways in which it has 'produced' other countries and cultures for domestic consumption. Travel writing is analyzed as a form of cultural imperialism from the different perspectives of two literary scholars and an historian heavily influenced by the 'literary turn', the turn to textual analysis. While the emphases vary, for Mills and Melman focus on women writers, Pratt on both men and women, all three are concerned to see gender as an important variable in the construction of colonial and imperial discourses.

Sara Mills was fascinated to find 'hundreds' of women travel writers writing from the mid nineteenth century onwards and has focused her work mainly on the British. Having moved from an earlier position in which she maintained that women travel writers were outside of the colonial relation, she argues in this book that they "were unable to adopt the imperial voice with the ease with which male writers did', they were more tentative and less able to assert the 'truths' of British rule without qualification (p. 3). She suggests that there is textual unease around the contradictions between imperialism and femininity and that women's texts constitute counter-hegemonic voices within colonial discourse. The 